\title{
Cooperation in Countering Corruption as a Condition for National Security: International Legal Framework
}

\author{
Valentyna Drozd * 1 [0000-0002-7687-7138], Yuliia Chornous 2 [0000-0001-9710-4858], \\ Liudmyla Havryliuk 1 [0000-0002-9441-4073] \\ ${ }^{1}$ State Research Institute of the Ministry of Internal Affairs of Ukraine, Kyiv, Ukraine \\ ${ }^{2}$ National Academy of Internal Affairs, Kyiv, Ukraine \\ *valusha.drozd@gmail.com
}

\begin{abstract}
Effective detection, investigation and prevention of transnational corruption-related crimes depends directly on depends on a coordinated and clearly regulated procedure for interaction between the authorized bodies of foreign States. This is the implementation of a system of organizational measures and procedural actions defined by criminal procedure legislation and international treaties as their integral part. The study reveals that the system of actions counteracting these crimes in the course of cooperation at international level takes forms provided by law. These are international legal assistance; extradition of a criminal suspect; transfer of criminal proceedings; transfer of persons sentenced to States of their nationality or permanent residence in order to serve his/her sentence; international search; exchange of information. International engagement in these forms is subject to strict observance of all human rights, and in particular of the citizens of own State, in the course of criminal procedure in a foreign State. The focus is on new promising forms of international cooperation against corruption-related offences: covert investigations and investigations of international joint investigation teams. It is emphasized that measures cooperation at international level in detecting, investigating and preventing corruption-related crimes are systematically implemented, comprehensive and aimed at achieving the common objective of identifying, detecting and investigating corruption-related criminal offences, ensuring the judicial consideration of the case, as well as creating conditions for the subsequent implementation of preventive activities, that is, eliminating the causes and conditions that have facilitated the commission of crimes. The effective action against corruption-related crimes requires implementation at the State, regional levels, as well as globally, with the participation of State authorities and law enforcement agencies, international and voluntary organizations, citizens and their associations.
\end{abstract}

Keywords: corruption-related criminal offence, international cooperation, investigation, joint investigation teams, criminal proceedings.

\section{INTRODUCTION}

Considering the current characterization of transnational corruption-related crimes, it is impossible to achieve the objectives of criminal proceedings effectively without international cooperation measures. Accordingly, targeted and systematic teamwork, involving State authorities and law enforcement bodies, international and voluntary organizations, citizens and their associations is a prerequisite for international engagement in the investigation of corruption-related crimes.

The further implementation of legal reform in Ukraine, the European integration development of our State and the orientation towards international democratic standards make the investigation of corruption-related criminal offences of particular relevance, and it is under the focus at the international, regional and national levels.

Corruption-related criminal offences committed at international level have the features of transnational organized criminal groups. The transnational organized crime is characterised by a high level of social danger, a system of criminal activities and the cohesion of its members. The participants of transnational organized criminal groups are organized according to certain criteria. These may include hometown relations (originating from one State or region), religious or cultural traditions, or family relationship. Frequently the 
unifying factor is professional performance. These groups "specialize" in the commission of a certain type (group) of crimes. The group is clearly constructed, specifying the leader, groups of "elite," "asset," "informers," "performers" etc. All tasks are planned in advance and assigned to specific performers, and a system of penalties is provided for failure to perform them or for improper performance. Frequently peculiar "codes of conduct" are developed to be strictly observed by all members of the criminal association. A separate "block" of activity concerns security: from the security of the members of the group up to the complex of measures to conceal hierarchical criminal system. New equipment, new firearms, video surveillance, advanced high-security communications are used.

According to scientists (Kyslyi et al., 2021), an important characteristic of transnational organized criminal groups is the presence of corrupt factors, the system of connections in different State authorities and law enforcement [1].

Considering world trends, only coordinated actions by States, interrelated by many links in political, economic and social life, can perform positive results in the system of actions against corruption, which encroaches on all sectors of public relations, as well as ensure investigation of corruption, that is, corruptionrelated criminal offences.

\section{RESEARCH METHODOLOGY}

The aim of the study is to highlight specificities of cooperation at international level against corruptionrelated crimes of special danger, that is, transnational. For this, a number of tasks should be undertaken: to reveal the content of international cooperation and to define its forms; to characterize international corruptionrelated crimes and to highlight the signs of performance of actors committing them; to reveal the procedure for teamwork of competent actors of different States, representatives of international organizations empowered against such acts; to determine the importance of international counteracting corruptionrelated crimes as a condition for national and international security.

The study is based on an analysis of international and national legislation, theoretical findings of domestic and foreign scholars and empirical evidence $[2,3,4,5]$.

\section{RESULTS OF THE STUDY}

At the international level, the leading international organisations have adopted a system of international treaties that define the international illegality of corruption and bind Member States to establish them as crimes in national criminal legislation and to effectively combat corruption.
Thus, international illegality and the principles for the implementation of international cooperation measures by the competent authorities of States in preventing and combating corruption are defined in the provisions of the Convention on Laundering, Search, Seizure and Confiscation of the Proceeds from Crime of 1990, the United Nations Convention against Transnational Organized Crime of 2000 with the Protocol of 2004 and special international agreements on combating corruption. These are Criminal Law Convention on Corruption of 1999 with the Additional Protocol of 2003, Civil Law Convention on Corruption of 1999, United Nations Convention against Corruption of 2003, etc.

A wide range of States are parties to these international instruments, since most of them are adopted within the framework of the United Nations (193 States of the world are involved in the international organization), as well as of the Council of Europe (composed of 47 States) that opens up great opportunities for cooperation.

In Ukraine, the criminal illegality of corruption offenses is defined in the Criminal Code of Ukraine of 2001 [6], and the procedure for criminal proceedings against them is regulated by the Criminal Procedure Code of Ukraine of 2012 [7].

It should be determined that law enforcement against these crimes is not limited to the investigation but also involves the detection and prevention by special forces and means, including covert, with the involvement of international and non-governmental establishments, citizens, using other special procedures for criminal proceedings.

At the current stage, it is important to perform such activities in accordance with international standards for national and international security.

The concept of "international standards" is a generalized concept encompassing the requirements for certain activities, according to the relevant legal and regulatory framework, the requirements of the international community and the best practical experience of foreign States. For example, scientists (Parkhomenko et al., 2020) argue that nowadays the fulfilment of Ukraine's international obligations and compliance [8] of the legal system of our State with international and European standards are an important mission. The incorporation of universally accepted world standards and values into domestic constitutions and legislation is achieved by enshrining basic principles of cooperation in joint treaties [9]. This involves the implementation of systemic measures, and above all improvement of the legal system of the State, as well as the practice of law application.

Interaction in criminal proceedings on corruptionrelated crimes at international level provides a system of organizational measures and procedural actions defined 
by criminal procedure legislation and international treaties as their integral part.

According to the review of empirical sources and scientific literature [10], typically international cooperation measures in such interaction are in the forms as follows:

1) international legal assistance, extradition of a criminal suspect, transfer of criminal proceedings in order to investigate criminal offenses;

2) transfer of persons sentenced to States of their nationality or permanent residence in order to serve his/her sentence;

3) international search;

4) information exchange.

International cooperation in these forms is subject to strict observance of human rights and freedoms, and their comprehensive implementation.

The most common form of international cooperation, such as cases on corruption-related offences, is international legal assistance, which involves procedural actions on behalf of the competent foreign authority.

International legal assistance, similar to other types (forms) of collaboration in criminal proceedings, is implemented between the authorised (central) and competent bodies of States. These bodies are determined by each State in accordance with its domestic legislation and the specific organization of the law enforcement system by submitting statements and notifications to the international agreement on the basis of which the interaction is carried out, each State Party shall designate the entities authorized to carry out the outlined tasks. In Ukraine, these are the Prosecutor-General's Office (during pre-trial stages) and the Ministry of Justice (during a court trial). The analysis [11] of the practice of foreign States reveals that competent authorities empowered to execute requests for international legal assistance and other forms of international cooperation in criminal proceedings are primarily bodies conducting pre-trial investigation.

Interaction with foreign competent authorities of States, their authorized persons is characterized by a number of features that relate to its legal basis, participants, features of implementation, and so on. In particular: regulation by international law and principles of reciprocity, observance of State sovereignty; ensuring the confidentiality of information; specific performers of certain tasks; taking into account the language barrier, territorial remoteness, differences in the domestic legislation of each State, whose representatives are involved in the interaction. To ensure proper interaction, a number of preparatory organizational and technical measures should be applied.
Extradition is an important form of countering corruption-related crimes at international level. This form of cooperation involves not only the transfer of a criminal suspect (accused) to the law enforcement agencies of a State that has initiated extradition, but also a range of procedural and organizational measures, aimed at preventing attempts of a person to evade investigative bodies, to continue to engage in corrupt activities, to evade search, at ensuring the preservation of sources of evidence and illegally gained proceeds, and at confirming the circumstances, which may impede extradition etc.

Previously, as a rule, a person (suspected or accused of corruption) is wanted, and this is the international search.

International search is a set of procedural, search, reference, organizational, technical and other measures taken by the competent authorities of the State initiating the search and by the authorities of the requested foreign States aimed at identification, seizure, arrest and extradition of wanted persons. The Interpol shall be involved in the international search, as well as the Interpol National Central Bureaus of member countries shall be involved in the international search.

Moreover, according to determined functions, regarding the issues of preventing and combatting corruption, the National Agency on Corruption Prevention, a central executive authority of Ukraine with a special status, responsible for the formation and implementation of public anti-corruption policy, is involved in international cooperation. In addition, the National Agency of Ukraine for finding, tracing and management of assets derived from corruption and other crimes [12]. This State authority forms the trend of development of State policy on effective counteraction to corruption-related crimes. In addition, the system of measures to detect, search, arrest proceeds from crime.

\section{DISCUSSION}

States' international cooperation measures are regulated by international instruments on countering corruption, regarding international legal assistance, etc. For example, a number of international cooperation measures in the investigation of corruption-related criminal offences are regulated by the United Nations Convention against Transnational Organized Crime of 2000 [13], the Second Additional Protocol to the European Convention on Mutual Assistance in Criminal Matters of 2001 [14] and others.

For example, according to art. 8 of the United Nations Convention against Transnational Organized Crime of 2000 [13], at the level of Member States, the obligation to implement the system of measures to establish socially dangerous corruption actions as crimes in domestic legislation of each State Party. 
The Second Additional Protocol to the European Convention on Mutual Assistance in Criminal Matters of 2001 [14], in addition to a number of measures, regulates "covert investigations" as a measure of international cooperation in criminal proceedings.

Scientists (Cherniavskyi et al., 2020) argue that nowadays the international legal basis for interaction of countries of the world in the field of covert investigations (criminal intelligence, investigative activities) exists [15].

Covert investigations require to ensure the safety not only of those involved in the investigation, but also of their relatives and friends who are at risk of pressure or manipulation. This system of measures may include: personal protection, protection of housing or property, as well as the provision and development of a system of notification of the existing danger; use of technical means of covert obtaining of information; conspiracy of the person's appearance; conducting a closed trial. It is important to establish a reliable information exchange system.

The legal, as well as organizational and tactical, framework for the exchange of information will be further studied.

A new and promising form of interaction of States is the establishment and operation of international joint investigation teams. Their activities are based on provisions of international (conventions, treaties, agreements) and domestic legislation (laws and by-laws) etc.

The activities of joint investigation teams in the investigation of corruption-related crimes as an area of global and national law enforcement activities of the State have legal, organizational, methodological and personnel aspects. International cooperation in the form of joint investigation teams enables to combine the efforts of the law enforcement agencies of several States, to involve the assistance of forensic institutions and international organizations in order to effectively accomplish the tasks set. In addition, the principle of clear distribution of powers and assignment of duties among law enforcement agencies, which directly implement interaction (pre-trial investigation bodies) and the bodies responsible for organizing and coordinating such interaction should be applied.

It is important to bear in mind the comprehensiveness of the activities of the joint investigation teams and their ultimate objective - to detect, investigate and prevent crimes, including corruption-related ones, to prosecute cases and to address causes and conditions, which facilitate the commission of crimes driven by the criminal intent of corruption.

The intensification of this form of international cooperation is provided for by the content of legal instruments [16] and the requirements of practical activities.

It should be noted that any form of interaction involves information exchange. Bearing in mind the different forms of expression of the activities and the range of actors involved the information exchange should be considered as a separate form of international cooperation. Interpol and Europol contribute to this form of cooperation in preventing and combating corruption.

For example, with the help of Interpol it is possible to obtain information that will describe: the illegal and criminal experience of a particular person; the alleged perpetrators of criminal offences; the range of relations, contacts, the place of residence of such persons; information on the crossing of borders by a particular person; the mechanism for the commission of a corruption-related criminal offence, a specific way of realising the criminal intent; a transnational organized criminal group; legal entities involved in illegal or criminal activities; analytical, statistical and background information on necessary issues.

The advantage of Interpol is that it is possible to exchange information on the $24 / 7$ system, which provides high-quality and confidential 24-hour-a-day direct access to the information resources of the Interpol General Secretariat, to exchange information between the National Central Bureaus of Interpol of different countries.

Generally, the exchange of information is one of Europol's priorities. A significant percentage of the exchange of information is support of the detection, investigation and prevention of corruption-related crimes specifically. The system of cooperation in the exchange of information involves Europol member States, as well as third States, on the basis of reciprocity. Such activities are subject to confidentiality, and Europol and Interpol also have a well-established system of cooperation to carry out joint tasks to counter criminal acts, including corruption-related ones.

Interaction of competent actors in the exchange of information may be as follows:

1) one-time, when the pre-trial investigation body of Ukraine requests the relevant law enforcement agencies of one or more foreign States regarding legal assistance (another form of international cooperation) or regarding international police cooperation. It should be noted that such a request may include more than one issue or task;

2) periodic, when the pre-trial investigation body of Ukraine repeatedly requests law enforcement agencies of a foreign State or States;

3) constant, when the law enforcement agencies of a foreign State or States interact the entire period of proceedings in a criminal or operative-search case. This type of interaction is typical, in particular, for multi- 
episode criminal proceedings on transnational economicand corruption-related crimes; interaction is also constant during the international search for the accused.

Accordingly, the interaction at the initiative of the law enforcement agencies of foreign States can be classified.

In all cases, an interaction involves activities by means of some actions, operations, techniques and practises. Its efficiency suggests that it cannot be reduced to a single technique.

The principles of international exchange of information on preventing and combating corruption are regulated by the content of a number of international treaties to which Ukraine is a party.

Provisions of international treaties are reflected in domestic legislation of Ukraine.

Information exchanged by competent authorities during international cooperation should be timely, mutual, detailed and as precise as possible. Such information should be provided in an appropriate form, as determined by international treaties and the laws of States.

With regard to procedural forms of information exchange, the most frequent form of such exchange is international legal assistance, and the data obtained by that means (records of various procedural acts, certificates, checks on database) is used in proving by the competent authorities of the State, which makes a request, in the investigation of corruption offences.

Information is exchanged in a non-procedural manner between individual representatives of the competent authorities of States. Such information should be of a guiding nature, facilitating further decision-making.

\section{CONCLUSIONS}

International cooperation aimed at the effective action against corruption-related crimes is implemented at different levels: the State (initial), regional (subsequent) and international (final, global), with the participation of State authorities and law enforcement bodies, international and voluntary organizations, citizens and their associations according to international and national legislation.

The grounds for establishing an act of corruption as an international crime are the danger to society, the violation of international security and the rule of law; the existence of a special international treaty to combat such an act or special provisions in a treaty that establish a certain act as crime internationally. The study proves that corruption-related criminal offences are international crimes. They are characterized by a specific mechanism of commission, actors, victims, the scale of the commission and the specific object of the offence. Such acts are punishable under national law on the basis of current provisions of international law.

In order to effectively combat corruption-related crimes at the global level, which is a prerequisite for international and national security, it is important to consider a number of factors. From our perspective, the key one is the consideration of the comprehensiveness of both traditional and new international cooperation activities and their ultimate goal, that is, effective fight against corruption-related crimes.

\section{REFERENCES}

[1] Kyslyi, A. Kasapohlu, S. Shvets, V. Padalko, R. and Nikonov, M. (2021), "Characteristics of transnational organized criminal groups and features of the investigation of their criminal activities", Journal of Legal, Ethical and Regulatory Issues, vol. 24, issue 4, available at: https://www.abacademies.org/articles/characteristi cs-of-transnational-organized-criminal-groupsand-features-of-the-investigation-of-theircriminal-activities-10807.html

[2] Korystin, Oleksandr and Svyrydiuk, Nataliia (2021), "Activities of Illegal Weapons Criminal Component of Hybrid Threats", Proceedings of the International Conference on Economics, Law and Education Research (ELER 2021), vol. 170, 22 March, pp. 86-91, DOI: 10.2991/aebmr.k.210320.016

[3] Korystin, Oleksandr and Svyrydiuk, Nataliia (2021), "Formation of security competences in law enforcement activities", Nauka i Pravookhorona, vol. 1 (51), pp. 191-198, DOI: 10.36486/np.2021.1(51).20

[4] Korystin, O.Y. Nekrasov, V.A. Krivolapchuk, V.O. and Sviridyuk, N.P. (2019), "The Phenomenology of Money Laundering in Ukraine", Financial and credit activities: problems of theory and practice, vol. 2 (29), pp. 374-382, DOI: $10.18371 /$ fcaptp.v2i29.171949

[5] Korystin, Oleksandr and Svyrydiuk, Nataliia (2020), "Methodological principles of risk assessment in law enforcement activity", Nauka $i$ Pravookhorona, vol. 3 (49), pp. 191-198, DOI: $10.36486 / \mathrm{np} .2020 .3(49)$

[6] Kryminalnyi kodeks Ukrainy [Criminal Code of Ukraine], 5 kvitniya 2001, no. 2341-III, available at: https://zakon.rada.gov.ua/laws/show/234114\#Text

[7] Kryminalnyi protsesualnyi kodeks Ukrainy [Criminal Procedure Code of Ukraine], 13 kvitniya 2012, no. 4651-VI, available at http://zakon2.rada.gov.ua/laws/show/4651-172 
[8] Rabail, S. Satti and Fakeeha, Jafari (2015), "Reviewing Existing Forensic Models to Propose a Cyber Forensic Investigation Process Model for Higher Educational Institutes", IJCNIS, vol. 7, no. 5, pp. 16-24, DOI: $10.5815 / \mathrm{ijcnis} .2015 .05 .03$

[9] Parkhomenko, N. Voloshyna, I. Tarakhonych, T. Tykhomyrov, O. and Husariev, S. (2020), "Theoretical Basis of Implementation of International Standards and European Principles in Ukrainian Legislation", Journal of Legal, Ethical and Regulatory Issues, vol. 23 (4), available at: https://www.abacademies.org/articles/theoreticalbasis-of-implementation-of-internationalstandards-and-european-principles-in-ukrainianlegislation-9399.html

[10] Cherniavskyi, S.S. Holovkin, B.M. Chornous, Yu.M. Bodnar, V.Y. and Zhuk, I.V. (2019), "International cooperation in the field of fighting crime: directions, levels and forms of realization", Journal of Legal, Ethical and Regulatory Issues, vol. 22 (3), pp. 1-1, available at: https://www.abacademies.org/articles/international -cooperation-in-the-field-of-fighting-crimedirections-levels-and-forms-of-realization8346.html.

[11] Gaurav, Kumar and Rajeev, Kumar (2021), "Analysis of Arithmetic and Huffman Compression Techniques by Using DWT-DCT”, International Journal of Image, Graphics and Signal Processing, vol. 13, no. 4, pp. 63-70, DOI: $10.5815 /$ ijigsp.2021.04.05

[12] Takhtai, O.V. (ed.) (2020), Naukovo-praktychnyi komentar Zakonu Ukrainy "Pro zapobihannia koruptsii” [Scientific and practical commentary on the Law of Ukraine "On Prevention of Corruption"], Yurinkom Inter, Kyiv, Ukraine.

[13] Konventsiia Orhanizatsii Obiednanykh Natsii proty transnatsionalnoi orhanizovanoi zlochynnosti 2000 roku: mizhnar. dok. vid 15 lystop. 2000 r. [United Nations Convention against Transnational Organized Crime of November 15, 2000], available at: https://zakon.rada.gov.ua/laws/show/995_789

[14] Druhyi dodatkovyi protokol do Yevropeiskoi konventsii pro vzaiemnu pravovu dopomohu $u$ kryminalnykh spravakh: mizhnar. dok. vid 8 lystop. $2001 r$. [Second Additional Protocol to the European Convention on Mutual Assistance in Criminal Matters of November 8, 2001], available at: https://zakon.rada.gov.ua/laws/show/994_518

[15] Cherniavskyi, S.S. Hribov, M.L. Nebytov, A.A. Kniaziev, S.M. and Telenyk, S.S. (2020), "The Forms of International Co-Operation in the Area of Undercover Investigations", Journal of Legal, Ethical and Regulatory Issues, vol. 23 (1), https://www.abacademies.org/articles/the-formsof-international-cooperation-in-the-area-ofundercover-investigations-9021.html.

[16] Uhoda pro asotsiatsiiu mizh Ukrainoiu, z odniiei storony, ta Yevropeiskym Soiuzom, Yevropeiskym spivtovarystvom $z$ atomnoi enerhii $i$ yikhnimy derzhavamy-chlenamy, $z$ inshoi storony: mizhnar. dok. vid 27 cherv. 2014 r. [Association Agreement between Ukraine, of the one part, and the European Union, the European Atomic Energy Community and their Member States, of the other part of June 27, 2014], available at https://zakon.rada.gov.ua/laws/show/984_011\#Te $\mathrm{xt}$ 